\title{
Ricin Perspective in Bioterrorism
}

\author{
Virginia I. Roxas-Duncan ${ }^{1}$ and Leonard A. Smith ${ }^{2}$ \\ ${ }^{1}$ Integrated Toxicology Division, \\ U.S. Army Medical Research Institute of Infectious Diseases, \\ ${ }^{2}$ Senior Research Scientist (ST) for Medical Countermeasures Technology, \\ Office of Chief Scientist, U.S. Army Medical Research Institute of Infectious Diseases,
}

USA

\section{Introduction}

Ricin is one of the most toxic and easily produced plant toxins. It is derived from the castor plant, Ricinus communis (Fig. 1), a shrub native to Africa but currently is being cultivated in many areas of the world for its co mmercial products, primarily castor oil. The seeds of $R$. communis, commonly called beans (although not a true bean) (Fig. 2), are oblong, brown, and have a thick mottled shell sometimes used to make decorative necklaces and bracelets. Castor seeds contain 40 to $60 \%$ vegetable oil that is rich in triglycerides, mainly ricinolein (McKeon et al., 1999). Castor oil is used in a number of products. For many years, purified castor oil has been ingested as a human nutritional supplement, emetic, or purgative worldwide (Scarpa and Guerci, 1982; Caupin, 1997; Olsnes, 2004). In addition to castor oil production, castor plants are also being grown for aesthetic (ornamental garden bush) and ecological values. It is used extensively as a decorative plant in parks and other public areas. Ecologically, despite the ricin being poisonous to humans and many animals, $R$. communis is the host plant of insects including moths and butterflies, and is also used as a food plant by some Lepidopteran larvae and birds.

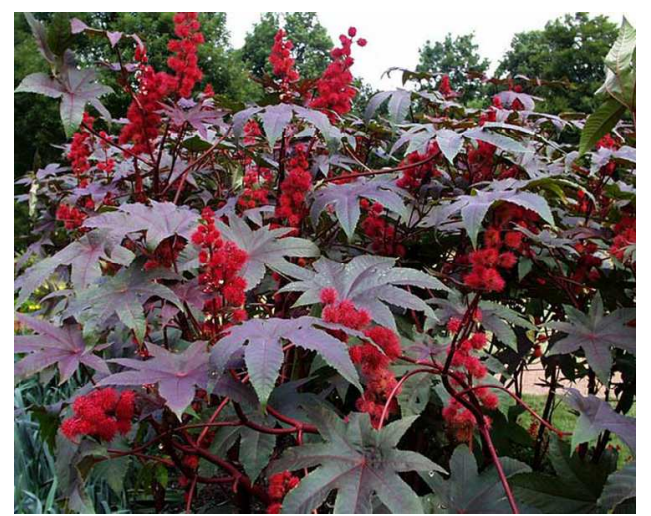

Fig. 1. Castor plant, Ricinus communis, a large shrub having large palmate leaves and spiny capsules containing seeds that are the source of castor oil and ricin (Adapted from http://dtirp.dtra.mil/images/RicinusCommunis.jpg) 
Castor seeds contain large amounts of ricin, which is also present in lower concentrations throughout the plant. Ricin content significantly varies among cultivars/accessions and may range from 0.1 to $4 \%$ of the weight of the seed (Auld et al., 2003; Baldoni et al., 2011; Pinkerton et al., 1999). Ricin is one of the most potent poisons in the plant kingdom (Lee \& Wang, 2005). Because of the wide availability of its source plants, ease of production, stability, and lethal potency, ricin toxin is considered to be a bioterrorism threat. Ricin is the most common biological agent used in biocrimes, and has also been reported as one of the most prevalent agents involved in WMD (weapons of mass destructions) investigations (FBI, n.d.). Recent attempted uses of ricin by various extremists and radical groups have heightened concerns regarding ricin's potential for urban terrorism.

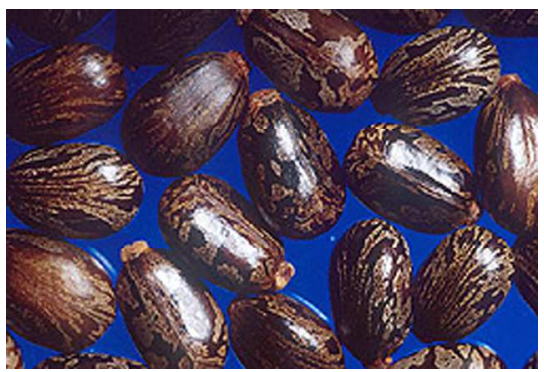

Fig. 2. Castor seeds (Adapted from

http://www.ars.usda.gov/is/AR/archive/jan01/plant0101.htm)

\section{History, biological warfare and terrorism}

The castor plant belongs to the genus Ricinus of the Euphorbiaceae or spurge family (Atsmon, 1985). R. communis is indigenous to the southeastern Mediterranean region, eastern Africa, and India, but is now widespread throughout temperate and subtropical regions (McKeon et al., 2000; Phillips \& Rix, 1999). The gourd mentioned in the Book of Jonah (Jon 4:6-9; Old Testament), bears the Hebrew name kikayon, and is presumed to be the kiki of the Egyptians, the castor-oil plant (Easton's Bible Dictionary, n.d.). It is commonly known as "Palm of Christ" or Palma Christi, that derives from castor oil's ability to heal wounds and cure ailments. Castor seeds have been found in Egyptian tombs dating back to $4000 \mathrm{BC}$, and were used in folk medicines against a wide variety of diseases. The plant has been cultivated for its commercial products, primarily castor oil, for at least 4000 years (Olsnes, 2004). Castor oil was used in rituals of sacrifice to please the gods in early civilizations. In Ancient Egypt and in Europe, it has been used for lighting, body ointments, improving hair growth and texture, and medicinal purposes, where it was regarded as a folk medicine. In India, castor oil has been documented since 2000 BC and was mainly used in lamps and in local medicine as a laxative, purgative, cathartic and other ethnomedical systems. In China, castor seed and its oil have been prescribed for centuries in local medicine for internal use. In Italy, castor oil was used as an instrument of coercion by the Squadristi, the Fascists armed squads of dictator Benito Mussolini; this idea originated from Gabriele D` Annunzio, a controversial nationalist, poet and war veteran (MacDonald, 1999). Political dissidents and regime opponents were forced to ingest the oil in large amounts, triggering severe diarrhea and dehydration that oftentimes led to death (New World Encyclopedia, n.d.). 
In recent centuries, however, natural castor oil was at first identified as a laxative and as a lubricant for the wheels of wagons and carts, as well as aircrafts during World War I (WWI). Today, castor oil (extracted minus the ricin) has a wide variety of commercial applications (International Castor Oil Association, ICOA, 1992). It is used for medicinal purposes both internally, as a strong and effective purgative or cathartic, and externally to treat corns, among other purposes (Sims \& Frey, 2005). Castor oil and its derivatives also have numerous industrial merits, being used in a wide variety of products, such as the basic ingredient in racing motor oil for high-performance engines, a fuel additive for two-cycle engines, a primary raw material in the production of nylons and other resins and fibers, and a component in paint and varnish, insulation, fabric coatings, soap, ink, plastics, hydraulic fluids, lubricants, guns, insecticidal oils, cosmetics, and antifungal compounds (Brugsch, 1960; Caupin, 1997; McKeon et al., 1999; Sims \& Frey, 2005). Because of its economic benefits and myriads of uses, castor seeds are currently being produced in more than 30 countries in the world. In 2008, world's production of castor oil totaled to 1,605,362 metric tons (MT) (Food and Agricultural Organization of the United Nations Statistical Database, FAOSTAT, 2011); the leading producers include India (1,171,000 MT), China (190,000 MT), and Brazil (122,140 MT). After oil extraction and inactivation of ricin, the defatted waste "mash" (also called castor bean meal) is used as animal feed while the seed husks are used as high nitrogen fertilizer (Kole, 2011).

Ricin toxin was discovered in 1888 by Hermann Stillmark, a student at the Dorpat University in Estonia (Stillmark, 1888, as cited in Franz and Jaax, 1997). During Stillmark's extensive research, he also observed that ricin caused agglutination of erythrocytes and precipitation of serum proteins (Olsnes, 2004). Olsnes and Phil (1972) demonstrated that ricin inhibited protein synthesis, and suggested that the effects resulted from restricted elongation of nascent polypeptide chain. Subsequent studies revealed that the molecular target of the toxin was the 60S ribosomal subunit (Olsnes and Phil, 1982).

In the last decade, immunotoxins using the ricin A-chain chemically-linked to monoclonal antibodies have been used as an alternative in therapies against cancer, AIDS and other illnesses (Engert et al., 1997; Schnell et al., 2003; Youn et al., 2005). Ricin-based immunotoxins, some of which contained deglycosylated ricin A chain conjugated to either the anti-CD22 antibody RFB4 (Amlot et al., 1993; Sausville et al., 1995), or its Fab fragment (Vitetta et al., 1991) have also been shown to provide enhanced therapeutic efficacy and resulted in improved antitumor activity (Li et al., 2005; Kreitman et al., 2005; Vitetta, 2006). However, the U.S. Food and Drug Administration (FDA) has placed a hold on the clinical testing of RTA-based immunotoxins because they caused vascular leak syndrome (VLS) in humans.

\subsection{Biological warfare and terrorism}

\subsubsection{History of ricin as a biological weapon}

During WWI, ricin was investigated as a potential offensive biological weapon. Two methods of weaponizing the toxin were explored, i.e., bullets and shrapnel coated with ricin, or a 'dust cloud' of toxin inhaled into the lungs (Smart, 1997). Nonetheless, the thermal instability of ricin constrained its initial use in exploding shells, and ethical and treaty issues limited its use as a poison or blinding agents (Hunt et al., 1918, as cited in Millard \& 
LeClaire, 2007). WWI ended before the toxin could be weaponized and tested. During WWII, ricin was produced in hundreds of kilograms and armed into W bombs (ricincontaining bombs), but apparently was never used in battle (Franz \& Jaax, 1997). Although its toxicity made it marginally better over existing agents, ricin was surpassed by the even more potent biological agents of the time. Interest in ricin continued for a short period after WWII, but soon subsided when the U.S. Army Chemical Corps began a program to weaponize sarin. During the Cold War, the Soviet Union also studied ricin as a possible biological weapons agent. Ken Alibek, a former top official involved in Russia's biological weapons program who defected to the U.S. in 1991, claimed that Russia developed ricin toxin as a weapon, and that the ricin toxin used against the Bulgarian dissident Georgi Markov, as well Vladimir Kostov (another Bulgarian exile in Paris), was concocted in Russian laboratories (Maman \& Yehezkelli, 2005). During 1989, approximately $10 \mathrm{~L}$ of concentrated ricin solution was reportedly manufactured at Salman Park just south of Baghdad, some of which were used in animal testing and as payload in artillery shells (Zilinskas, 1997). More recently, ricin has been used by terrorist organizations (CDC, 2008). In 2002, a report emerged that Ansar al-Islam, a Sunni Islamic group allegedly linked to Osama Bin Laden's al-Qaeda organization, had been testing biological weapons including ricin at a small facility in northern Iraq (BBC News, 20 August 2002). A news item documented evidence of the manufacture of ricin and botulinum toxin in Iraq (Mendenhall, 2003). Syria was also believed to have produced unknown quantities of the toxin. Iran allegedly procured 120 tons of castor beans in 1992, presumably for ricin production (Croddy \& Wirtz, 2005). Ricin was also found in Afghanistan after the collapse of the Taliban Government in 2001 (GlobalSecurity.org, n.d.; Barceloux, 2008).

Ricin is currently monitored as a Schedule 1 toxic chemical under the Convention on the Prohibition of the Development, Production, Stockpiling and Use of Chemical Weapons and on Their Destruction (CWC). Also, the intentional use of ricin or related toxins as weapons is prohibited under the 1972 Convention on the Prohibition of the Development, Production and Stockpiling of Bacteriological (Biological) and Toxin Weapons and on Their Destruction (BTWC) (Millard \& Le Claire, 2007; Poli, 2007). The possession or transfer of ricin, abrin, or genes encoding functional forms of these toxins is also regulated in the U.S. by the Centers for Disease Control and Prevention (CDC) Select Agents and Toxins Program.

Although ricin's potential use as a military weapon was investigated, its utility over conventional weaponry remains disputed. Despite its toxicity, ricin is less potent than other agents such as botulinum neurotoxin or anthrax. Kortepeter \& Parker (1999) estimated that eight metric tons of ricin would have to be aerosolized over a $100 \mathrm{~km}^{2}$ area to achieve about $50 \%$ casualty, whereas only kilogram quantities of anthrax spores would cause the same effect. Furthermore, dispersal of ricin on a wide scale is logistically impractical. Thus, while ricin is easy to produce, it is not as likely to cause as many casualties as other agents (Schep et al., 2009). However, it has been the agent of choice in numerous biocrimes (see below).

\subsubsection{Ricin as a terrorist weapon}

Ricin has been classified by the CDC as a Category B agent. Category B agents are moderately easy to disseminate, can cause morbidity and low mortality, and include Coxiella burnetii, Brucella spp, Burkholderia mallei, B. pseudomallei, alphaviruses (VEE, EEE, WEE), 
Rickettsia prowazekii, toxins (e.g., ricin, Staphylococcal enterotoxin B, epsilon toxin of Clostridium perfringens), Chlamydia psittaci, food safety threats (e.g., Salmonella spp., Escherichia coli O157:H7, Shigella), and water safety threats (e.g. Vibrio cholerae, Cryptosporidium parvum) (Rotz et al., 2002). Though ricin is not considered an effective weapon of mass destruction, its potential as a weapon of terror cannot be discounted. Further, ricin's notoriety is likely driven by the ready availability of castor beans, press coverage, and popularization on the internet. In the U.S. for example, the use of ricin as a biological agent in bioterrorism and homicides is of particular concern especially after the events of September 11, 2001. Worldwide, numerous cases involving the possession, experimentation, or planned misuse of ricin by bioterrorists and extremist groups have been investigated or prosecuted by law enforcement agencies (Franz and Jaax, 1997; James Martin Center for Nonproliferation Studies (CNS), 2004; Research International, Inc. (RII), 2011). The following incidents have reportedly involved the use and/or possession of ricin.

- On September 7, 1978 while waiting at a bus stop in London, a Bulgarian dissident, Georgi Markov, felt a jab in the back of his right thigh and saw a man picking up an umbrella (Crompton \& Gall, 1980). Markov, a 49-year-old novelist and playwriter had published and broadcasted anticommunist views. An assassin reportedly injected a small pellet of ricin (believed to have been supplied by the KGB), into Markov's right thigh using a weapon in the shape of an umbrella (Maman \& Yehezkelli, 2005). He subsequently developed severe gastroenteritis, high fever, and died 3 days later (discussed in detail later in this chapter). At autopsy, a small 1.53-mm metallic sphere that had 2 tiny holes and could hold a volume of $0.28 \mathrm{~mm}^{3}$, was found at the wound site. No specific isolation of any poison was possible. Because of the small volume and rapid demise of the patient, ricin was believed to be the only capable inciting agent. The coroner recreated the scenario by injecting a pig with a somewhat greater dose than Markov had received (Crompton \& Gall, 1980). With an illness similar to Markov's, the animal died 26 hours later. Thereafter the coroner was satisfied that Markov had been unlawfully killed by a tiny pellet containing 0.2 to $0.5 \mathrm{mg}$ dose of ricin (Musshoff \& Madea, 2009). The KGB denied any involvement although high-profile defectors Oleg Kalugin and Oleg Gordievsky have since confirmed the KGB's involvement (Pearce, 2011).

- In 1981, exposed CIA double agent Boris Korczak was reportedly shot with a ricin-laced pellet (Carus, 2002). He survived this assassination attempt which was thought to be the work of the KGB.

- In 1982, William A. Chanslor, a Texas attorney was sentenced to jail for 3 years and fined $\$ 5,000$ for plotting to kill his 39-year-old wife with ricin. He claimed that he wanted the ricin to assist his wife, paralyzed from the waist down due to a stroke, in committing suicide (Time Magazine, 16 August 1982).

- In 1983, two brothers were arrested by the Federal Bureau of Investigation (FBI) for producing an ounce of pure ricin (RII, 2011).

- In 1983 and 1985, Montgomery Todd Meeks, a high school senior was tried and convicted of attempted murder and solicitation to murder in connection with a plot to kill his father using ricin (Trager, 1985, as cited in Carus (2002). He claimed that the act was motivated by his father's abuse (RII, 2011).

- In 1991, four members of the Minnesota Patriots Council, a radical tax-protesting militia organization, acquired castor beans and planned to use ricin to assassinate local deputy 
sheriffs, U.S. Marshals, and IRS agents. Despite having no specific expertise in biological warfare, they extracted about $0.7 \mathrm{~g}$ of $5 \%$ ricin, which was enough to kill about 100 people. Two members were convicted in 1994, and the other two in 1995 under the Biological Weapons Anti-Terrorism Act (BWATA) law (RII, 2011).

- On April 21, 1992, the Washington Post published an article regarding the unsuccessful attempt to poison the famous Soviet dissident Alexander Solzhenitsyn with the same lethal chemical (thought to be ricin) used to kill Bulgarian dissident Georgi Markov in London in 1978 (Remnick, 21 April 1992).

- In December 1995, Thomas Lewis Lavy, an electrician from Valdez, Alaska was arrested in Onia, Arkansas for possession of ricin (Kifner, 2005). In April 1993, he was caught while trying to smuggle $130 \mathrm{~g}$ of ricin and other materials from Alaska into Canada, and was then charged under BWATA with possession of a biological toxin with intent to kill. Lavy killed himself in his prison cell several days after his arrest (RII, 2011).

- In 1995, a federal case was brought against Dr. Ray W. Mettetal, Jr., a neurologist at Rockingham Memorial Hospital in Harrisonburg, Virginia, after ricin was discovered in his possession and also of providing false information (Carus, 2002).

- In 1995, Deborah Green, a non-practicing oncologist from Prairie Village, Kansas, attempted to murder her husband, Michael Farrar, a cardiologist, with ricin (Musick, 25 May 2000; Carus 2002). Green had purchased the castor beans through a special order from a garden center in Kansas City, Missouri, and placed them in Farrar's food. It is unclear if she extracted the ricin or merely added the beans to the food. Later, Farrar had to undergo multiple heart and brain surgeries related to the poisoning (CNS, 2004).

- In 1997, a man was indicted under the provisions of BWATA for possessing ricin and nicotine sulfate. He pled guilty to manufacturing ricin and was sentenced to more than 12 years in prison (Cordesman, 2002).

- On August 25, 1998, Dwayne Lee Kuehl was arrested in Escanaba, Michigan, for producing ricin with intent to use it against an Escanaba city housing inspector (RII 2011).

- In November 1999, FBI agents apprehended James Kenneth Gluck in Tampa, Florida, for threatening to kill court officials in Jefferson County, Colorado with ricin (The New York Times, 08 November 1999).

- In August 2001, the FSB (Russian Federal Security Service) told the Itar-Tass news service it had intercepted a recorded conversation between two Chechen field commanders (Brigadier General Rizvan Chitigov and field commander Hizir Alhazurov) about instructions on the homemade production of poisons against Russian troops (RII, 2011). Russian authorities reportedly raided Chitigov's home and seized materials, including instructions on how to produce ricin from castor beans, a small chemical laboratory, three homemade explosives, two land mines, and 30 grenades (Gad, 2007).

- In June 2002, Ken Olson, an Agilent software engineer, was convicted of ricin possession (Tizon, 2004). He was given a 13-year, 9-month sentence in April 2004.

- In August 2002, the Sunni miltant group Ansar al-Islam was reported to be involved in testing biological agents including ricin on barnyard animals and perhaps even an unwitting human subject (BBC News, 20 August 2002). 
- In December 2002, six terrorist suspects were arrested in Manchester, England. Their apartment was serving as a "ricin laboratory." Among them was a 27-year-old chemist who was producing the toxin (CDC, 2003a).

- In January 2003, authorities discovered traces of ricin in the apartment of six Algerians in Wood Green, northern London (Hopkins \& Branigan, 08 January 2003). They also discovered castor beans and equipment for crushing the beans. Those arrested are believed to be part of a terrorist cell known as the "Chechen network" which may have ties to the Algerian group behind the millennium bomb plots in the U.S. All but one of the suspects was acquitted of charges in April, 2005 (Research International, 2011).

- In October 2003, an envelope with a threatening note and a sealed container that had ricin in it was discovered at a mail processing and distribution facility in Greenville, South Carolina. The note threatened to poison water supplies if demands were not met (CDC, 2003b).

- In February 2004, traces of ricin were discovered on an automatic mail sorter in the mailroom of the Dirksen Senate Office building in Washington, D.C which handled mail addressed to Senate Majority Leader Bill Frist (CNN.com, 04 February 2004).

- In January 2005, the FBI arrested an Ocala, Florida man after agents found ricin and other products in the home he lives in with his mother (CNN.com, 14 January 2005).

- On October 3, 2006, a survivalist from Phoenix, Arizona was sentenced to 7 years in prison for attempting to manufacture ricin (Martens, 2006).

- In 2007, traces of ricin had been found at Limerick Prison (Lally, 2007). The ricin was smuggled into Ireland from the U.S. in a contact lens case, to be used in an assassination plot. An arrest was made before the ricin could be used (RII, 2011).

- In November 2008, Roger Von Bergendorff was fined and sentenced to 3.5 years in prison for having ricin and unregistered firearm silencers. In February 2008, Bergendorff was living in a motel room in Las Vegas, Nevada when he was taken to a hospital in critical condition. Authorities recovered castor beans, a weapons cache, a copy of "The Anarchist Cookbook" with a page about ricin marked, and 4 crude grams of ricin in his room. Investigators also found respirators, gloves and chemicals that could be used in the production of ricin in one of Bergendorff's storage units in Utah (Powers, 18 November 2008).

- In June 2009, a father and son, Ian and Nicky Davison were arrested after the discovery of ricin at a house in County Durham (BBC News, 06 June 2009). Ian Davidson was sentenced to 10 years in May 2010 for preparing acts of terrorism, three counts of possessing material useful to commit acts of terrorism and possessing a prohibited weapon; his son was given 2 years youth detention for possessing material useful to commit acts of terrorism (Wainwright, 2010).In January 2011, The FBI has arrested the owner of a Coventry Township, Ohio home for unlawful possession of ricin (Sharma, 29 January 2011).

- In June 2011, Michael Crooker, a former Agawam man, was sentenced to 15 years in federal prison for illegally possessing ricin and threatening a prosecutor (Associated Press, AP, 22 June 2011). In another report during the same period, a British citizen, Asim Kauser, was brought to court on charges including possessing instructions for producing ricin (Global Security Network, GSN, 17 June 2011). 
The above events clearly demonstrate that ricin is readily available or accessible, relatively easy to produce, and seemingly, a biological weapon of choice by extremist groups and individuals. Hence, it should be seriously considered as a potential bioterrorism threat agent.

\section{Description of the agent}

\subsection{Overview of ribosome-inactivating proteins}

Ricin belongs to a diverse family of ribosome-inactivating proteins (RIPs) that include numerous other toxins from a wide variety of plants, as well as potent bacterial Shiga and Shiga-like toxins (Endo et al., 1988). RIPs possess N-glycosidase activity that depurinates a highly conserved adenine residue within the specific 14 nucleotide region (also known as asarcin/ricin loop) of the $28 \mathrm{~S}$ ribosomal RNA (rRNA) subunit of $60 \mathrm{~S}$ ribosome (Endo et al., 1987; Endo \& Tsurugi, 1987). There are three types of RIPs. Type 1 RIPs are monomeric Nglycosidase enzymes of approximately $30 \mathrm{kDA}$ molecular mass, and are frequently found in higher plants, e.g., pokeweed antiviral protein, trichosanthin, saporin, and luffin (Nielsen \& Boston, 2001). In general, type I RIPs are not cytotoxic because they lack the means of entering the cell (B chain) to inactivate ribosomes (Lord et al., 1994).

Type 2 RIPs are glycosylated heterodimers possessing an N-glycosidase enzyme (denoted A chain) linked through a disulfide bond to a galactose-binding lectin (denoted B-chain) that facilitates endocytosis (Lord et al., 1994; Stirpe \& Battelli, 2006). Type 2 RIPs include potent toxins such as ricin, abrin (isolated from the seeds of rosary pea, Abrus precatorius), modeccin (from the fruits and roots of Adenia digitata), volkensin (from the roots of A. volkensii), and viscumins (from mistletoe, Viscum album; Lord et al., 1994). Some type 2 RIPs possess an aberrant or non-functional B-chain, hence are relatively nontoxic. These include nigrin $b$ from the elderberry plant (Sambucus nigra), lectins from winter aconite (Eranthis hyemalis), and ebulin lectins from dwarf elder (S. ebulus).

Type 3 RIPs are the least common class and resemble type I plant RIPs in catalytic activity and overall net charge (Nielsen \& Boston, 2001). They are synthesized as inactive precursor molecules with a polypeptide insert in the active site region of the A chain domain (Chaudhry et al., 1994).

\subsubsection{Biochemistry of ricin}

Ricin is the most well-characterized member of the type 2 RIPs. It consists of two glycoprotein subunits, designated A chain (RTA) and B chain (RTB), of approximately equal molecular mass ( $32 \mathrm{kDa}$ ) linked by a single disulfide bond (Fig. 3). The ricin toxin is stored in the matrix of the castor seed, together with a $120 \mathrm{kDa}$ lectin called R. communis agglutinin I (RCA). RCA is composed of two ricin-like dimers. Although the nucleotide sequences of ricin and RCA are similar, these proteins are products of distinct genes (Kole, 2011); it has been suggested that the ricin gene evolved first and then duplicated to give rise to the RCA gene (Ready et al., 1984). Compared with ricin, RCA is virtually nontoxic (Olsnes et al., 1974) but is a powerful red blood cell agglutinin (Hegde \& Podder, 1992). 


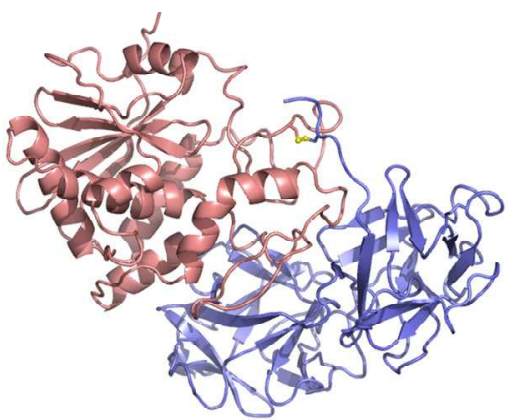

Fig. 3. Three-dimensional representation of ricin. The A chain (RTA) is depicted in red, the B chain (RTB) in blue, and the disulfide bond in yellow. (Image courtesy of Dr. Mark A. Olson, Integrated Toxicology Division, USAMRIID, Fort Detrick, MD).

\subsubsection{Primary structure of ricin/RCA}

The ricin protein's coding region consists of a 24 amino acid N-terminal signal sequence preceding a 266 amino acid RTA. The RTB has 262 amino acids. A 12-amino acid linker joins the two chains. The nontranslated mRNA regions of ricin and RCA are identical (Roberts, et al., 1985; Lamb et al., 1985). The signal peptide preceding the RTA in both lectins and the linker peptide joining the RTA and RTB are also alike in size and amino acid sequence. Overall, the RCA and RTA chains are $93 \%$ homologous (18 amino acid variants) while the corresponding B chains differ in 41 amino acids, and are $84 \%$ homologous (Lamb et al., 1985).

\subsubsection{Ricin secondary structure}

The carboxyl-terminal end of the RTA folds into a domain that interacts between the two domains of the B chain (Montfort et al., 1987). A disulfide bond is formed at amino acid 259 of the RTA and amino acid 4 of the RTB (Robertus, 1988; 1991; Lord et al., 1994). Thirty percent of the RTA protein is helical (Fig. 4). The RTA folds into three somewhat arbitrary domains. The active site cleft of the RTA is located at the interface between all three domains. A conformational change occurs in the active site when the RTA is released from the RTB.

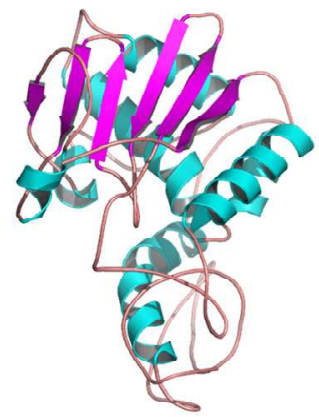

Fig. 4. Ribbon representation of RTA. The RTA has three structural domains and exhibits a substantial amount of secondary structure. Color schemes: cyan = helix; magenta $=$ strands; red $=$ coil regions. (Image courtesy of Dr. Mark A. Olson, Integrated Toxicology Division, USAMRIID, Fort Detrick, MD). 


\subsection{Pathogenesis}

Ricin is a toxalbumin, a biological toxin whose mechanism of action is inhibition of protein synthesis in eukaryotic cells which results in cell death (CDC, 2006a). The dimeric A-B chain structure is crucial to cellular internalization and subsequent toxicity. Cell entry by ricin involves a series of steps, summarized as follows: 1) the RTB portion of the ricin molecule binds to cell surface glycolipids or glycoproteins possessing 1,4-linked galactose residues; 2) once bound to the cell surface, the toxin is internalized by endocytosis and routed to the cytosol. The presence of the B-chain facilitates transport of the A-chain into the cytosol; 3) toxin entry into early endosomes; 4) ricin vesicular transport from early endosomes to the trans-Golgi network; 5) retrograde vesicular transport through the Golgi network to reach the endoplasmic reticulum; 6) reduction of the disulfide bond connecting RTA and RTB; 7) partial unfolding of the RTA to render it translocationally competent to cross the endoplasmic reticulum (Endo et al., 1987; Olsnes \& Koslov, 2001; Lord et al., 1994; 2003). Transport to the cytosol is the rate-limiting step during the decline in protein synthesis (Hudson and Neville, 1987).

Once transported from the ER to the cytoplasm, the RTA can interact with the ribosome, which acts as a suicidal chaperone stimulating proper refolding and resumption of catalytic activity (Lord et al., 2003). Ricin has a Michaelis constant $\left(K_{\mathrm{M}}\right)$ of $0.1 \mu \mathrm{mol} / \mathrm{L}$ for ribosomes and an enzymatic constant $\left(K_{\text {cat }}\right)$ of $1,500 / \mathrm{min}$. It depurinates a specific adenosine residue (A4324) near the $3^{\prime}$ end of $28 \mathrm{~S}$ ribosomal RNA subunit in the $60 \mathrm{~S}$ ribosome subunit (Robertus, 1991). This halts the binding of elongation factor-2, which then results in the inhibition of protein synthesis in eukaryotic cells (Endo et al., 1987). Catalytic studies showed that single ricin molecule in the cytosol can inactivate over 1500 ribosomes per minute and eventually kills the cell (Olsnes et al.,1975; Cawley and Houston, 1979).

Ricin is more active against animal than plant or bacterial ribosomes (Cawley and Houston, 1979). Ribosomes which lack the specific $28 \mathrm{~S}$ subunit containing the GAGA tetranucleotide sequence are generally not susceptible to the toxin.

\subsection{Toxicity}

Ricin's toxicity is dependent on a number of factors including route of exposure (inhalation, parenteral (injection), ingestion, dermal contact, or ocular contact), amount of toxin administered, and animal species.

\subsubsection{Route of administration}

Ricin is extremely toxic by inhalation, and least potent by the oral route. In mice, the approximate dose that is lethal to $50 \%$ of the exposed population $\left(\mathrm{LD}_{50}\right)$ and time to death are, respectively, 3-5 $\mu \mathrm{g} / \mathrm{kg}$ (Franz and Jaax, 1997) and 60 hours by inhalation (Kortepeter et al., 2001a), $20 \mathrm{mg} / \mathrm{kg}$ and 85 hours by ingestion (Franz and Jaax, 1997), $5 \mu \mathrm{g} / \mathrm{kg}$ and 90 hours by intravenous injection (Franz and Jaax, 1997), and $24 \mu \mathrm{g} / \mathrm{kg}$ and 100 hours by subcutaneous injection (Franz and Jaax, 1997). Low oral toxicity is possibly due to poor toxin absorption and partial degradation in the gut. Higher toxicities by other routes may be related to accessibility of target-cell populations and the availability of toxin receptors 
among cell types. Skin testing in mice showed no dermal toxicity, indicating poor absorption across the skin (Wannemacher \& Anderson, 2005).

\subsubsection{Amount of toxin administered}

Ingestion and mastication of 3-6 castor beans is the estimated fatal dose in adults; the fatal dose in children is not known, but is likely less (CDC, 2006a). Most cases of castor bean ingestion do not result in poisoning, because: a) it is difficult for ricin to be released from ingested castor beans; $b$ ) ricin release requires mastication, and the degree of mastication is likely to be important in determining the extent of poisoning; and c) ricin is not as well absorbed through the gastrointestinal tract when compared to injection or inhalation (CDC, 2006a).

\subsubsection{Animal species}

The lethality of ricin by different routes in several animal species was summarized by Millard \& LeClaire (2007). By ingestion, the hens were the least sensitive to the toxin $\left(\mathrm{LD}_{50}=\right.$ $14 \mathrm{~g} / \mathrm{kg})$, and the horses were the most sensitive $\left(\mathrm{LD}_{50}=0.1 \mathrm{~g} / \mathrm{kg}\right)$. By injection, rabbits had an $\mathrm{LD}_{50}=0.1 \mu \mathrm{g} / \mathrm{kg}$ (i.m.), and $0.5 \mu \mathrm{g} / \mathrm{kg}$ (i.v.), while guinea pigs had $<1.1 \mu \mathrm{g} / \mathrm{kg}$ (i.v.) and $0.8 \mu \mathrm{g} / \mathrm{kg}$ (i.m.) (Millard \& LeClaire, 2007).

\subsection{Human toxicity}

Limited information is available regarding human toxicity. Based on animal experiments and accidental human exposures, the approximate $\mathrm{LD}_{50}$ and time to death for humans are, respectively, $3 \mu \mathrm{g} / \mathrm{kg}$ and 36-72 hours by inhalation, $30 \mu \mathrm{g} / \mathrm{kg}$ and $6-8$ days by ingestion, 3 $\mu \mathrm{g} / \mathrm{kg}$ and 36-72 hours by intravenous injection, and $500 \mu \mathrm{g}$ and 3-6 days by subcutaneous injection (based on Georgi Markov's assassination) (Franz \& Jaax, 1997; Maman \& Yehezkelli, 2005; Mirarchi, 2010).

The vulnerability of certain populations (e.g., children, pregnant women, the elderly, those with immunosuppression, or underlying respiratory or gastrointestinal tract disease) to the health effects of ricin exposure is unknown; however, persons with pre-existing tissue irritation or damage may sustain further injury upon ricin exposure (CDC, 2006a).

\subsection{Transmission}

Ricin may adhere to skin, nonetheless, person-to-person transmission through casual contact has not been reported. Ricin is transmitted by the airborne route through release of the toxin in the form of a powder, or a mist, or reaerosolization of ricin into the air from disturbed surfaces (CDC, 2006a). However, to be effective, the toxin would need to be dispersed in particles smaller than 5 microns (CDC, 2006a).

\section{Clinical symptoms, signs and pathology}

The clinical signs, symptoms, and pathological manifestations of ricin toxicity vary with the dose and route of exposure, as detailed below. For symptomatic patients, the clinical course presents with the rapid onset of nausea, vomiting, and abdominal pain. Gastrointestinal 
bleeding, anuria, diarrhea, cramps, and vascular collapse can also occur (Challoner \& McCarron, 1990). Most symptoms develop less than 6 hours after ingestion, although the lag time from ingestion of castor seeds to onset of symptoms has ranged from 15 minutes to almost 10 hours. Progression to death occurs within 36 to 72 hours of exposure, depending on the route of exposure and the dose received (CDC, 2008).

\subsection{Injection}

In humans, subcutaneous or intramuscular injection of high doses of ricin results in severe local lymphoid necrosis, gastrointestinal hemorrhage, liver necrosis, diffuse nephritis, and diffuse splenitis. Ricin injection leads to necrosis at the injection site, which may predispose one to secondary infection (Passeron et al., 2004). Crompton \& Gall (1980) summarized the clinical signs and symptoms for the Bulgarian dissident Georgi Markov, whose wellpublicized assassination was attributed to intramuscular injection of ricin $(\sim 500 \mu \mathrm{g})$, as follows: there was an immediate local pain, followed by general weakness within about 5 hours. This was followed by elevated temperature, nausea, and vomiting 15 to 24 hours later. Thirty-six hours after the incident, the patient was admitted to the hospital feeling very ill. He exhibited fever, tachycardia, normal blood pressure, swollen and sore lymph nodes in the affected groin, and and a 6-cm diameter area of induration and inflammation was observed at the injection site on his thigh. Over the next 48 hours, he became suddenly hypotensive and tachycardic; developed GI hemorrhage, hypovolemic shock, and renal failure. His white blood count was $26,300 / \mathrm{mm}^{3}$. Early on the third day after the attack, he became anuric and began vomiting blood. An electrocardiogram demonstrated complete atrioventricular conduction block. He died shortly thereafter; at the time of death, his white blood count was $33,200 / \mathrm{mm}^{3}$. The autopsy revealed pulmonary edema that was thought to have been secondary to Markov's cardiac failure, hemorrhagic necrosis of the small bowel, and hemorrhages in lymph nodes near the injection site, myocardium, testicles, and pancreas (Crompton and Gall, 1980).

A case of a 20-year-old male who allegedly committed suicide by injecting (s.c.) castor bean extract was reported to show severe weakness, nausea, dizziness, headache, chest, back, and abdominal pain 36 hours after the injection (Targosz et al., 2002). This patient subsequently developed a bleeding diathesis, liver failure, and renal failure. He succumbed to cardiac arrest. Postmortem examination revealed hemorrhagic foci in the brain, myocardium, and the pleura (Targosz et al., 2002).

A 36-year-old chemist who allegedly injected (i.m.) himself with an unknown amount of ricin prepared from homogenized castor seeds reportedly experienced headache and rigors 10 hours after exposure. He then developed anorexia, nausea, sinus tachycardia, lymphadenopathy at the injection sites, and erythematous areas around the puncture wounds (Fine et al., 1992).

In a clinical study involving cancer patients, intravenous administration of 40 low doses (18$20 \mu \mathrm{g} / \mathrm{m}^{2}$ of estimated body surface area) of ricin was well tolerated (Fodstad et al., 1984). Flu-like symptoms with fatigue and muscular pain were common, and sometimes nausea and vomiting occurred. The symptoms began 4 to 6 hours after administration and lasted for 1 to 2 days. Phase I/II clinical trials of two experimental immunotoxins containing 
deglycosylated RTA (RFT5.dgA and Ki-4.dgA) administered i.v. to Hodgkins' lymphoma patients revealed maximum tolerated doses (MTDs) of 15 and $5 \mathrm{mg} / \mathrm{m}^{2}$ of estimated body surface area for RFT5.dgA and Ki-4.dgA, respectively (Schnell et al., 2003).

\subsection{Oral intoxication}

Ricin is less toxic by oral ingestion than by other routes (Rauber \& Heard, 1985), probably due to poor absorption of the toxin and possibly partial enzymatic degradation in the digestive tract. The effects of oral intoxication vary among individuals, are dose dependent, and have different signs and symptoms. Rauber \& Heard (1985) reviewed 751 cases of castor bean ingestion and reported 14 fatalities (1.9\% death rate). The number of beans ingested by patients who died greatly varied. For instance, of the two lethal cases of oral intoxication documented since 1930, one involved a 24-year-old man who ate 15 to 20 beans, and the other was a 15-year-old boy who had 10 to 12 beans. All of the described serious, or fatal cases of castor bean ingestion have the same general clinical history: rapid (less than a few hours) onset of nausea, vomiting, and abdominal pain followed by diarrhea, hemorrhage from the anus, anuria, cramps, dilation of the pupils, fever, thirst, sore throat, headache, vascular collapse, and shock. Death occurred on the third day or later. The most common autopsy findings in oral intoxication were multifocal ulcerations and hemorrhages of gastric and small-intestinal mucosa, which may be quite severe; lymphoid necrosis in the mesenteric lymph nodes, gut-associated lymphoid tissue (GALT), and spleen; Kupffer cell and liver necrosis; diffuse nephritis; and diffuse splenitis (Rauber \& Heard, 1985; Bradberry et al., 2003).

\subsection{Inhalation}

There are no documented cases of aerosol exposure to ricin in humans. Lesions induced by oral and parenteral exposure are consistent with those from animal studies, suggesting that the same would hold true for aerosol exposures. An allergic syndrome has been reported in workers exposed to castor bean dust in or around castor oil-processing plants (Brugsch, 1960). The clinical picture is characterized by the sudden onset of congestion of the nose and throat, itchiness of the eyes, urticaria, and tightness of the chest. In more severe cases, wheezing can last for several hours, and may lead to bronchial asthma. Affected individuals respond to symptomatic therapy and removal from the exposure source.

\section{Diagnosis}

Ricin poisoning can be diagnosed based on clinical and epidemiological information, e.g., ingestion of castor beans, or occurrence of multiple cases during a short period, suggesting a common-source etiology (Wortmann, 2004). Ricin intoxication should be suspected if clinicians are presented with a number of patients having acute lung injury. A covert dispersion of aerosolized ricin is expected to be diagnosed, post factum, only after clinical symptoms occur (Kortepeter et al., 2001b). One common problem encountered in patients treated with ricin immunotoxins is the VLS, in which fluids leak from blood vessels leading to hypoalbumina, weight gain and pulmonary edema (Ghetie \& Vitetta, 1994a). In patients who may be targets of an assassination attempt, ricin injection should be considered if there 
are signs of rapid onset of symptoms similar to VLS. Ricin ingestion should be suspected if patients with gastrointestinal hemorrhage and hypotension have eaten from the same food source.

Because ricin is immunogenic, acute as well as convalescent sera should be obtained from patients 2 weeks after exposure for measurement of antibody response (Franz \& Jaax, 1997). Immunoassay (for blood or other body fluids) or immunohistochemistry techniques (for direct analysis of tissues) may be useful for confirming ricin intoxication (Poli et al., 2007). However, identification of the toxin in body fluids or tissues is challenging because ricin is bound very quickly, and is also metabolized before excretion (Ramsden et al., 1989).

Currently, two types of laboratory testing are available for suspected ricin exposures. For environmental cases (determined by the CDC for suspected exposures from the environment, or by the FDA for suspected exposures from food or medication), ricin can be detected qualitatively by time-resolved fluorescence immunoassay (TRFIA), and polymerase chain reaction (PCR) in specimens (e.g., filters, swabs, or wipes). For biologic samples, selected specimens can be assessed for urinary ricinine, a marker of ricin exposure, using HPLC-ESI-MS (CDC, 2006b).

The differential diagnoses of aerosol exposure to ricin include staphylococcal enterotoxin $B$ (SEB), community-acquired pneumonia, inhalational anthrax, Q fever, tularemia, plague, and exposure to pyrolysis by-products of organofluorine polymers, or other chemical warfare agents such as phosgene (Eitzen et al., 1998). For ingested ricin, differential diagnoses include enteric pathogens, enterotoxins, and other toxins, including caustic agents, mushroom species, hydrocarbons, and pharmaceuticals such as salicylates and colchicine. Several factors discriminate ricin intoxication from other agents, such as: 1) clinical progression despite antibiotics (as opposed to infectious agents); 2) lack of mediastinitis (as seen with pulmonary anthrax); 3) progressive decline in clinical status (patients exposed to SEB tend to stabilize), and a slower progression than patients exposed to phosgene (Eitzen et al., 1998; Kortepeter et al., 2001a; 2001b).

\subsection{Prognosis and cause of death}

Death from ricin exposure could occur within 36 to 72 hours (CDC, 2008). If death has not occurred within 3-5 days, the patient usually survives. A mortality rate of $1.9 \%$ (14 of 751 patients) was reported after castor bean ingestion (Rauber \& Heard, 1985). Even with little or no effective supportive care, the death rate in symptomatic patients has been approximately $6 \%$. No information is available regarding human mortality rate after ricin inhalation.

The exact cause of death from ricin poisoning possibly varies with route of exposure. Ricin ingestion results in ulceration and hemorrhage of the stomach and small intestine mucosa, necrosis of the mesenteric lymphatics, liver necrosis, nephritis, and splenitis (Poli et al., 2007). Injection of the toxin may lead to severe local lymphoid necrosis, gastrointestinal hemorrhage, liver necrosis, diffuse nephritis, and diffuse splenitis. Intravenous administration of ricin in rats resulted in diffuse damage to Kupffer cells within 4 hours, followed by endothelial cell damage, formation of thrombi in the liver vasculature, and finally, hepatocellular necrosis (Bingen et al., 1987; Derenzini et al., 1976). In mice, rats, and primates, high doses by inhalation 
apparently produce lethal pulmonary damage, probably due to hypoxemia resulting from massive pulmonary edema and alveolar flooding (Poli et al., 2007).

\section{Medical management}

Currently, there is no FDA-approved therapeutic for ricin exposure. Countermeasures that have demonstrated capability to disrupt the ricin intoxication process include vaccines and antibody therapy. Both rely on the ability of antibody to prevent the binding of ricin to cell receptors. To ensure maximum protection, the vaccine must be given before exposure, and sufficient antibody must be produced. Similarly, administration of preformed antibodies affords maximum protection if antibody is present before exposure.

Treatment is largely symptomatic and basically supportive to minimize the effects of the poisoning. Because ricin acts rapidly and irreversibly (directly on lung parenchyma after inhalation or is distributed rapidly to vital organs after parenteral exposure), postexposure therapy is more challenging than with slowly processed, peripherally acting agents that can be treated with antibiotics (Franz \& Jaax, 1997).

\subsection{Vaccination and passive protection}

Inhalational exposure is best countered with active vaccination or prophylactic administration of aerosolized specific antibody (Franz and Jaax, 1997). However, there is currently no licensed vaccine available. Development of a ricin vaccine previously focused on either a deglycosylated ricin A chain or formalin-inactivated toxoid (Hewetson et al., 1996). Both vaccines confer protection against aerosolized ricin. Nevertheless, ricin is not completely inactivated by formalin and may retain some of its enzymatic activity (albeit approximately 1,000-fold lower than native ricin). Deglycosylated ricin A chain may lead to local or systemic VLS.

Recent research has focused on developing recombinant RTA subunit vaccines devoid of cytotoxicity and other potential deleterious activities. Several ricin vaccines candidates that are based on engineered RTA molecules have shown protection with different animal models, but demonstration of their human protection proved to be more challenging (Vitetta et al., 2005). USAMRIID has engineered a recombinant ricin vaccine 1-33/44-198 (rRTA 1-33/44-198) (RVEc), with increased protein stability over the parent RTA subunit and devoid of enzymatic (N-glycosidase) activity (Olson et al., 2004), lacking vascular leak activity (Porter et al., 2011) described in RTA-based immunotoxins, and fully protected vaccinated animals against supralethal aerosol challenges (McHugh et al., 2004; Carra et al., 2007). A cGLP pre-clinical toxicity study of RVEc in New Zealand white rabbits demonstrated that no treatment-related or toxicologically significant effects were observed with RVEc during this study (McClain et al., 2011). A phase I clinical study is ongoing at USAMRIID to evaluate the safety and immunogenicity of RVEc in humans (USAMRIID, 13 April 2011; AP, 13 April 2011).

A recombinant protein RTA vaccine, RiVax, has been developed based on mutations of both the enzymatic and a reported VLS-inducing site (Smallshaw et al., 2002). RiVax elicited 
protective immunity in mice, and had sufficient pre-clinical safety data (Smallshaw et al., 2005). Results from the initial Phase I human trial showed that RiVax appeared to be immunological and well tolerated in humans (Vitetta et al., 2006). However, while such results were encouraging, vaccine formulation and stability remain problematic. Hence, a lyophilized formulation that retained immunogenicity when stored at $4^{\circ} \mathrm{C}$ was developed (Smallshaw \& Vitetta, 2010; Marconescu et al., 2010).

Passive protection with aerosolized anti-ricin immunoglobulin (IgG) has also been evaluated as prophylaxis before aerosol challenge. Administration of nebulized anti-ricin IgG effectively protected against lung lesions and lethality in mice when challenged with an aerosol exposure to ricin (Poli et al., 1996). Extrapolation of these data to clearance rates of IgG from the airways of rabbits suggests that anti-ricin-specific antibodies may provide protection for up to 2 to 3 days or longer. These findings imply that inhaling protective antibody from a portable nebulizer just before an attack might provide some protection in nonimmune individuals (Poli et al., 1996). However, the window of opportunity for treatment by intravenous administration or inhalation of specific antibody after exposure is probably minimal at best.

Recent pre-clinical studies have shown the powerful protection afforded by neutralizing monoclonal antibodies (administered singly or in combination) against a lethal dose challenge of ricin, demonstrating proof of concept for passive immunotherapy for the treatment of ricin poisoning or for preexposure prophylaxis (Neal, 2010; 2011; Prigent, 2011).

\subsection{Supportive and specific therapy}

Supportive medical care depends on the route of exposure and clinical manifestations. For oral intoxication, supportive therapy includes intravenous fluid, electrolyte replacement, monitoring of liver and renal functions, gastric emptying/lavage, syrup of ipecac, cathartics, and, activated charcoal (Ellenhorn, 1997; Franz \& Jaax, 1997). Patients who have ingested beans and presented asymptomatic should remain under observation for 4-6 hours after ingestion. For inhalational intoxication, respiratory support is given as needed. Aerosolexposed patient may require the use of positive-pressure ventilator therapy, fluid and electrolyte replacement, antiinflammatory agents, and analgesics (Kortepeter et al., 2001b). Dermal exposures require supportive treatment. Percutaneous exposures would necessitate judicious use of intravenous fluids and monitoring for symptoms associated with VLS, including hypotension, edema, and pulmonary edema (Poli et al., 2007). Supportive care includes correction of coagulopathies, respiratory support, and monitoring for liver and renal failure .

Several research groups have engaged in the development of RTA active site inhibitors or RTB receptor antagonists as clinical antidotes against ricin poisoning, or as therapeutic adjuncts to vaccination. Small molecules that exhibited modest $\mathrm{IC}_{50}$ values (Bai et al., 2010; Wahome et al., 2010; Pang et al., 2011), including a compound that showed in vivo efficacy (Stechmann et al., 2010) have been described. An effective and essentially irreversible RTA inhibitor is thought to be practically useful as a pretreatment for military forces or civilian first-responders (Millard \& LeClaire, 2007). 


\section{Medical therapy of ricin}

In addition to studies pertaining to the natural toxicity of the protein, ricin has also been used extensively in the design of therapeutic immunotoxins. In such, ricin, RTA, or a related toxin is chemically or genetically linked to a binding ligand such as an antibody or growth factor that recognizes cancer cells, then it may be taken up by the cancer cells and ultimately kill them (Frankel, 1988). Immunotoxins using RTA or blocked ricin, have been evaluated in phase I clinical trials for control of several cancers (Ghetie \& Vitetta, 1994b; Lynch et al., 1997; Schnell et al., 2003; Vitetta, 2006).

\section{Summary}

Ricin is a potent toxin derived from the seeds of the castor plant, $R$. communis. Because of its potency, stability, worldwide availability, and relative ease of production, ricin is considered a significant biological warfare or terrorism threat. Ricin was developed as an aerosol biological weapon by the U.S. and its allies during WWII, although it was never used in battle. As a biological or chemical weapon, ricin has not been considered as very powerful in comparison with other agents such as botulinum neurotoxin or anthrax. However, its effectiveness as a discrete weapon of terror-targeted assassinations, biocrimes, or small-scale operations does raise potential concern. Ricin's popularity as well as its track record in actually being exploited by extremists groups and individuals highlight the need to be vigilant of its latent misuse. Clinical manifestations of ricin poisoning vary depending on the routes of exposure. Diagnosis is based upon both epidemiological and clinical parameters. Laboratory confirmation of clinical samples is possible by immunoassay but complicated by pharmacokinetic factors. Currently, there is no U.S. FDA-approved drug or vaccine against ricin poisoning. Treatment is purely supportive. Prophylaxis will be best accomplished by vaccination. Ricin vaccine candidates are currently in advanced development in laboratory and clinical trials.

\section{Acknowledgment and disclaimer}

This work was supported by Defense Threat Reduction Agency, JSTO-CBD Project Numbers CBM.VAXBT.03.10.RD.P.011 and CBCALL12-VAXBT4-1-0385. We are grateful to Dr. Mark A. Olson for providing the three-dimensional images of ricin, and Lorraine Farinick for assistance with graphics.

The opinions or assertions contained herein are the private views of the authors and are not necessarily the official views of the U.S. Army or the Department of Defense.

\section{References}

Amlot, P.L., Stone, M.J., Cunningham D, et al. (1993). A Phase I Study of an Anti-CD22deglycosylated Ricin A Chain Immunotoxin in the Treatment of B-cell Lymphomas Resistant to Conventional Therapy. Blood, Vol. 82, pp. 2624-2633, ISSN 0006-497

AP. (13 April 2011). Army Starts Clinical Trials on Ricin Vaccine, In: Army Times, 20072011. Available from http://www.armytimes.com/news/2011/04/ap-army-medicalresearch-ricin-041311/ 
AP. (22 June 2011). Former Agawam Man Sentenced for Ricin, Prosecutor Threat, In: Gazettenet.com, 04.08.2011. Available from

http:/ / www.gazettenet.com/2011/06/22/former-agawam-man-sentenced-forricin-prosecutor-threat

Atsmon, D. 1985. Castor. In: Oil Crops of the World, G. Robbelen, R.K. Downey \& A. Ashri (Eds), pp. 438-447, McGraw Hill Pub. Co., ISBN 0070530815, New York

Audi J, Belson M, Patel M, Schier, J. Osterloh, J. (2005). Ricin Poisoning: A Comprehensive Review. JAMA, Vol. 294, pp. 2342-2351, ISSN 0098-7484

Auld, D.L., Pinkerton, S.D., Boroda, E., et al. (2003). Registration of TTU-LRC Castor Germplasm with Reduced Levels of Ricin and RCA $\mathrm{A}_{120}$. Crop Science, Vol. 43, p.746747, Online ISSN 1435-0653; Print ISSN 0011-183X

Bai, Y., Watt, B., Wahome, P.G., et al. (2010). Identification of New Classes of Ricin Toxin Inhibitors by Virtual Screening. Toxicon, Vol. 56, pp. 526-534, ISSN 0041-0101

Baldoni, A.B., De Carvalho, M.H., Sousa, N.L., et al. (2011).Variability of ricin content in mature seeds of castor bean. Pesq Agropec Bras, Vol. 46 (7), Available from http:/ / www.scielo.br/scielo.php?pid=S0100-04X2011000700015\&script=sci_arttext

Balint, G.A. (1974). Ricin: the Toxic Protein of Castor Oil Seeds. Toxicology, Vol. 2, pp. 77-102, ISSN 0300-483X

Barceloux, D. (2008). Castor Bean and Ricin, In: Medical Toxicology of Natural Substances: Foods, Fungi, Medicinal Herbs, Plants, and Venomous Animals, pp. 718-726. John Wiley and Sons, ISBN 047172761X, 9780471727613, Hoboken, New Jersey

Bingen, A., Creppy, E.E., Gut, J.P., et al. (1987). The Kupffer Cell is the First Target in Ricininduced Hepatitis. J Submicrosc Cytol, Vol.19, pp. 247-256

BBC News (20 August 2002). U.S. Knew of bioterror Tests in Iraq, In: BBC News, 07.08.2011. Available from http://news.bbc.co.uk/2/hi/americas/2204321.stm

BBC News (06 June 2009). Pair Questioned over Ricin Find, In: BBC News, 07.08.2011. Available from http://news.bbc.co.uk/1/hi/8086701.stm

Bradberry, S.M., Dickens, K.J., Rice, P., et al. (2003). Ricin Poisoning. Toxicol Rev, Vol. 22, pp. 65-70, ISSN 1176-2551

Brugsch, H.G. (1960). Toxic Hazards: the Castor Bean. N Engl J Med, Vol. 62, pp. 1039-1040, ISSN 0028-4793

Carus, W.S. (2002). Bioterrorism and Biocrimes: The Illicit Use of Biological Agents since the 1900, Center for Counterproliferation Research, National Defense University, ISBN 9781410100238, Available from http:/ / books.google.com/books?id=1jEP8Ve4zwgC

Carra, J.H., Wannemacher, R.W., Tammariello, R.F., et al. (2007). Improved Formulation of a Recombinant Ricin A-chain Vaccine Increases Its Stability and Effective Antigenicity. Vaccine, Vol. 25, pp. 4149-4158, ISSN 0264-410X

Caupin, H.J. (1997). Products from Castor Oil: Past, Present, and Future, In: Lipid Technologies and Applications, F.D. Gunstone and F.B. Padley (Eds.), pp. 787-795, Marcel Dekker, Inc., ISBN 0-8247-9838-4, New York

Cawley, D.B. \& Houston, L.L. (1979). Effect of Sulfhydryl Reagents and Protease Inhibitors on Sodium Dodecyl Sulfate-heat Induced Dissociation of Ricinus communis Agglutinin. Biochem Biophys Acta, Vol. 81, pp. 51-62, ISSN 0006-3002

CDC. (2003a). Recognition, Management and Surveillance of Ricin-Associated Illness [Web cast script], December 30, 2003, 07082011. Available from 
http://www2.cdc.gov/phtn/webcast/ricin/RicinScript.rev.07-14-04.htm

CDC. (2003b). Investigation of a Ricin-containing Envelope at a Postal Facility: South Carolina. MMWR, Vol. 52(46), pp. 1129-1131 ISSN 01492195, 1545861X

CDC. (2006a). Ricin: Epidemiological Overview for Clinicians. 22.06.2011. Available from http://www.bt.cdc.gov/agent/ricin/clinicians/epidemiology.asp

CDC. (2006b). Laboratory Testing for Ricin. 19.09.2011. Available from http://www.bt.cdc.gov/agent/ricin/labtesting.asp

CDC. (2008). Facts about Ricin (Updated March 5, 2008). Available from http://www.bt.cdc.gov/agent/ricin/facts.asp

Chaudhry, B., Mu“ller-Uri, F., Cameron-Mills, V., et al. (1994). The Barley 60 kDa Jasmonateinduced Protein (JIP60) is a Novel Ribosome-inactivating protein. The Plant Journal, Vol. 6, pp. 815-24, ISSN (electronic) 1365-313X

Challoner, K.R. \& McCarron, M.M. (1990). Castor Bean Intoxication: Review of Reported Cases. Ann Emerg Med, Vol.19, pp. 1177-1183, ISSN 0196-0644

CNN.com (04 February 2004). Frist: Ricin Confirmed, But No Illness Reported, In: Cable News Network (CNN.com). 04.08.2011. Available from http:/ /articles.cnn.com/2004-02-03/us/senate.hazardous_1_deadly-toxin-ricindeadly-poison-mailroom?_s=PM: US

CNN.com. (14 January 2005). Florida Man Faces Bioweapon Charge, In: CNN.com 5.08.2011. Available from http://articles.cnn.com/2005-01-13/us/ricin.arrest_1_ricin-stevenmichael-ekberg-castor-beans?_s=PM:US

CNS. (2004). Combating the Spread of Weapons of Mass Destruction, In: James Martin Center for Nonproliferation Studies, 07.08.2011, Available from http://cns.miis.edu/ stories/pdfs/080229_ricin.pdf

Cordesman, A.H. (2002). Terrorism, Asymmetric Warfare and Weapons of Mass Destruction: Defending the U.S. Homeland, p. 28, Greenwood Publishing Group, ISBN 0275974278, Washington, DC

Croddy, E. \& Wirtz, J.J. (2005). Weapons of Mass Destruction: An Encyclopedia of Worldwide Policy, Technology, and History, Vol. 2, p. 241, ABC-CLIO, ISBN 1851094903 (hardback); ISBN 1-85109-495-4 (e-book), Santa Barbara, California

Crompton, R. \& Gall, D. (1980). Georgi Markov: Death in a Pellet. Med Leg J. Vol. 48, pp. 5162

Derenzini, M., Bonetti, E., Marionozzi, V., et al. (1976). Toxic Effects of Ricin: Studies on the Pathogenesis of Liver Lesions. Virchows Arch B Cell Pathol, Vol. 20, pp. 15-28, ISSN 0340-6075

Easton's Bible Dictionary. (n.d.). 22.06.2011. Available from http://www.sacred-texts.com/bib/ebd/ebd153.htm\#005

Eitzen, E., Pavlin, J., Cieslak, T, et al. (1998). Medical Management of Biological Casualties Handbook, $3^{\text {rd }}$ ed, 101-106. USAMRIID, Fort Detrick, MD

Ellenhorn, M.J. (1997). Ellenhorn's Medical Toxicology: Diagnosis and Treatment of Human Poisoning, 2nd ed, pp. 1847-1849, Williams \& Wilkins, ISBN-13: 9780683303872 ISBN-10: 0683303872, Baltimore, Maryland

Endo, Y. \& Tsurugi, K. (1987). RNA N-glycosidase Activity of Ricin A-chain. Mechanism of Action of the Toxic Lectin Ricin on Eukaryotic Ribosomes. J Biol Chem, 262, pp. 8128-8130, ISSN 0021-9258 
Endo Y, Mitsui K, Motizuki M, Tsurugi K. (1987). The Mechanism of Action of Ricin and Related Toxic Lectins on Eukaryotic Ribosomes. The Site and the Characteristics of the Modification in $28 \mathrm{~S}$ Ribosomal RNA Caused by the Toxins. J Biol Chem Vol. 262, pp. 5908-5912, ISSN 0021-9258

Endo, Y., Tsurugi, K. Yutsuodo, T., et al. (1988). Site of Action of a Vero Toxin (VT2) from Escherichia coli O157:H7 and of Shiga Toxin on Eukaryotic Rbosomes. RNA Nglycosidase Activity of the toxins. Eur J Biochem, Vol. 171, pp. 45-50, ISSN 0014-2956

Engert, A., Diehl, V., Schnell, R., et al. (1997). A Phase I Study of an Anti-CD25 Ricin- A chain Immunotoxins (RFT5-SMPT-dgA) in Patients with Refractory Hodgkin's Lymphoma. Blood Vol. 89, pp. 403-410, ISSN 0006-497

FAOSTAT (2011). 24.07.2011. Available from http://faostat.fao.org/site/339/default.aspx

Fine, D.R., Shepherd, H.A., Griffiths, G.D. \& Green, M. (1992) Sub-lethal Poisoning bySelfinjection with Ricin. Med Sci Law, Vol. 32, pp. 70-72

Fodstad, O., Kvalheim, G., Godal, A., et al. (1984). Phase I Study of the Plant Protein Ricin. Cancer Res, Vol. 44, pp. 862-865

Frankel, A. (1988). Immunotoxins, Volume 37 of Cancer Treatment and Research, 565 p. Kluwer Academic Publisher, ISBN 0898389844, 9780898389845, Norwell, Massachusetts

FBI (n.d.). Terrorism 2002-2005, In: U.S. Dept. of Justice, Federal Bureau of Investigation, Reports and Publications, 22.07.2011. Available from http://www.fbi.gov/stats-services/publications/terrorism-2002-2005

Franz, D.R. \& Jaax, N.K. (1997). Ricin Toxin, In: Medical Aspects of Chemical and Biological Warfare, Sidell F.R., Takafuji, E.T. \& Franz, D.R. (Eds), 631-642, Walter Reed Army Medical Center, Borden Institute, ISBN-10 9997320913, Washington, DC

Gad, S.C. (2007). Handbook of Pharmaceutical Biotechnology, Vol. 2. Of Pharmaceutical Development Series, p. 1598, John Wiley and Sons, Inc., ISBN 0471213861, 9780471213864, Hoboken, NJ

Ghetie, M.A. \& Vitetta, E. (1994a). Recent Developments in Immunotoxin Therapy. Current Opinion in Immunology, Vol. 6, pp. 707-714, ISSN 0952-7915

Ghetie, V. \& Vitetta, E. (1994b). Immunotoxins in the Therapy of Cancer: From Bench to Clinic. Pharmacol Ther Vol. 63, pp. 209-231, ISSN 0163-7258

GSN. (17 June 2011). U.K. Man Charged with Possessing Ricin Recipe, In: Global Security Newswire, 07.08.2011. Available from

http://gsn.nti.org/gsn/ nw_20110617_5703.php

GlobalSecurity.org. (n.d.). Weapons of Mass Destruction (WMD): Ricin, In: GlobalSecurity.org, 02.08.2011. Available from http://www.globalsecurity.org/wmd/intro/ bio_ricin.htm

Hegde, R., Podder, S.K. (1992). Studies on the Variants of the Protein Toxins Ricin and Abrin. Eur Jour Biochem, Vol. 204, No. 1, pp. 155-164, ISSN 0014-2956

Hewetson J., Rivera V., Lemley P., et al. (1996). A Formalinized Toxoid for Protection of Mice from Inhaled Ricin. Vacc Res, Vol. 4, pp. 179-187

Hopkins, N. \& Branigan, T. (08 January 2003). Poison Find Sparks Terror Alert, In: The Guardian, 07.08.2011. Available from http://www.guardian.co.uk/uk/2003/ jan/08/terrorism.alqaida

Hudson T. \& Neville, D.M., Jr. (1987). Temporal Separation of Protein Toxin Translocation from Processing Events. J Biol Chem, Vol. 262, pp. 16484-16494, ISSN 0021-9258 
ICOA. (1992). The Chemistry of Castor Oil and Its Derivatives and Their Applications. Westfield, New Jersey

Kifner, J. (2005). Man Arrested In Poison Case Kills Himself In Jail Cell, In: The New York Times, 01.08.2011. Available from

http:/ / www.nytimes.com/1995/12/24/us/man-arrested-in-poison-case-killshimself-in-jail-cell.html?pagewanted $=2 \& s r c=p m$.

Kole, C. (2011). Wild Crop Relatives - Genomic and Breeding Resources: Oilseeds, C. Kole, (Ed.), p. 295, Springer, ISBN 9783642148705, Available from http:// books.google.com/books?id=zWp--NMP3hAC

Kortepeter, M.G., Christopher, G., Cieslak, T., et al. (2001a). USAMRIID's Medical Management of Biological Casualties Handbook, 4th ed. USAMRIID, Fort Detrick, MD, pp. 130-137

Kortepeter, M.G., Cieslak, T.J., \& Eitzen, E.M. (2001b). Bioterrorism. J Environ Health, Vol. 63(6), pp. 21-24, ISSN 0022-0892

Kortepeter, M.G. \& Parker G.W. (1999). Potential biological weapons threats. Emerg Infect Dis, Vol. 5, pp. 523-527, ISSN 1080-6059

Kreitman, R.J., Squires, D.R., Stetler-Stevenson, et al. (2005). Phase I trial recombinant immunotoxin RFB4(dsFv)-PE38 (BL22) in patients with B-cell malignancies. J Clin Onco, Vol. 23, pp. 6719-6729, ISSN 0277-5379

Lally, C. (2007). Prison alert over ricin traces find, In: The Irish Times, 06.08.2011. Available from http://www.highbeam.com/doc/1P2-24880932.html

Lamb, F.I., Roberts, L.M., Lord, J.M. (1985). Nucleotide sequence of cloned cDNA coding for preproricin. European Journal of Biochemistry, Vol. 148, pp. 265-70.

Lee, M.D. \& Wang, R.Y. (2005). Toxalbumins, In: Critical Care Toxicology, J. Brent, K.L. Wallace, K.H. Burkhart, S.D. Phillips, J.W. Donovan (Eds.), 1345-1349, Elsevier Mosby, ISBN 0815143877, Philadelphia

Li, Z., Yu, T., Zhao, P. \& Ma, J. (2005). Immunotoxins and Cancer Therapy. Cell Mol Immunol, Vol. 2, pp. 106-112

Lord, J.M., Roberts, L.M. \& Robertus, J.D. (1994). Ricin: structure, mode of action, and some current applications. FASEB J, Vol. 8, pp. 201-208, ISSN 0892-6638

Lord, M.J., Jolliffe, N.A., Marsden, C.J., et al. (2003). Ricin: Mechanisms of Cytotoxicity. Toxicol Rev, Vol. 22, pp. 53-64, ISSN 1176-2551

Lynch, T. J. Jr., Lampert, J.M., Coral, F., et al. (1997). Immunotoxin Therapy of Small-cell lung cancer: A Phase I Study of N901-Blocked Ricin. J Clin Oncol, Vol. 15, pp. 723734, ISSN 0277-5379

MacDonald, H. (1999). Mussolini and Italian Fascism, pp. 15-17, Nelson Thornes, ISBN 9780748733866, Retrieved from http://books.google.com/books?id=221 W9vKkWrcC

Maman, M., \& Yehezkelli, Y. (2005). Ricin: a Possible, Non-infectious Biological Weapon, In: Bioterrorism and Infectious Agents, S. Fong and K. Alibek, (Eds.), 205-216, Springer Science and Business Media, ISBN-10 0-387-28294-7, New York, NY

Marconescu, P.S., Smallshaw, J.E., Pop, L.M., et al. (2010). Intradermal administration of RiVax protects mice from mucosal and systemic ricin intoxication. Vaccine, Vol. 28, pp. 5315-5322, ISSN: 0264-410X 
Martens, B. (2006). Owner of Northwoods Cabin Sentenced for Attempted Production of Ricin. WSAW.com, Oct 3, 2006. Available from http://www.wsaw.com/home/headlines/4294797.html

McHugh, C.A., Tammariello, R.F., Millard, C.B., Carra, J.H. (2004). Improved stability of a protein vaccine through elimination of a partially unfolded state. Protein Sci 13, pp. 2736-2743 ISSN 0961-8368

McKeon, T.A., Lin, J.T. and Stafford, A.E. (1999). Biosynthesis of ricinoleate in castor oil. Adv Exp Med Biol, Vol. 464, pp. 37-47, ISSN 0065-2598

McKeon, T.A., Chen, G.Q. \& Lin, J.T. (2000). Biochemical aspects of castor oil biosynthesis. Biochem Soc Trans. 28, pp. 972-974, ISSN 0300-5127

McLain, D.E., Horn, T.L., Detrisac, C.J., et al. (2011). Progress in biological threat agent vaccine development: a repeat-dose toxicity study of a recombinant ricin toxin Achain (rRTA) 1-33/44-198 vaccine (RVEc) in male and female New Zealand white rabbits. Int J Toxicol, Vol. 30, pp. 143-152 ISSN 1091-5818

Mendenhall, P. (2003). Positive test for terror toxins in Iraq. Evidence of ricin, botulinum at Islamic militants' camp. MSNBC.com, April 4, 2003. 07.08.2011. Available from http://www.msnbc.msn.com/id/3070394/ns/world_news/t/positive-test-terrortoxins-iraq/

Millard, C.B. \& LeClaire, R.D. (2007). Ricin and Related Toxins: Review and Perspective. In: Chemical Warfare Agents: Chemistry, Pharmacology, Toxicology, and Therapeutics, 2nd ed. J.A. Romano Jr. \& B.J. Lukey, (Eds.), 423-467. CRC Press, Taylor \& Francis Group, ISBN 978-1-4200-4661-8, Boca Raton, FL.

Mirarchi, F.L. (2010). CBRNE - Ricin, In: Medscape Reference, 10082011. Available from http://emedicine.medscape.com/article/830795-overview\#showall

Montfort, W., Villafranca, J.E., Monzingo, A.F., et al. (1987). The three-dimensional structure of ricin at $2.8 \AA$ proteins are targeted by different mechanisms. J Biol Chem, Vol. 262, pp. 5398-403, ISSN 0021-9258

Muldoon, D.F. \& Stohs, S.J (1994). Modulation of ricin toxicity in mice by biologically active substances. J Appl Toxicol, Vol. 14, pp.81-86, ISSN 0260-437X

Musick, J. (25 May 2000). Debora Green Back in Court. In: Pitch News, 19.08.2011. Available from http://www.pitch.com/kansascity/debora-green-back-incourt/Content?oid=2160233

Musshoff, F. \& Madea, B. (2009). Ricin Poisoning and Forensic Toxicolog. Drug Test Anal, Vol. 1, pp. 184-191, ISSN (printed) 1942-7603; ISSN (electronic) 1942-7611

Neal, L.M., O'Hara,J., Brey, R.N. 3rd, et al. (2010). A monoclonal immunoglobulin G antibody directed against an immunodominant linear epitope on the ricin A chain confers systemic and mucosal immunity to ricin. Infect Immun, Vol. 78, pp. 552-61, ISSN 0019-9567

Neal, L.M., McCarthy, E.A., Morris, C.R., et al. (2011). Vaccine-induced intestinal immunity to ricin toxin in the absence of secretory IgA. Vaccine, Vol. 29(4), pp. 681-689, ISSN 0264-410X

New World Encyclopedia (n.d.). 22.06.2011. Available from http://www.newworldencyclopedia.org/entry/Castor_oil_plant

Nielsen, K. and Boston, R.S. (2001) Ribosome-inactivating proteins: a plant perspective. Annu Rev Plant Physiol Plant Mol Biol, Vol. 52, pp. 785-816 
Olsnes, S. (2004). The history of ricin, abrin and related toxins. Toxicon, Vol. 44, pp. 361-370. ISSN 0041-0101

Olsnes, S. \& Pihl, A. (1972). Ricin - a potent inhibitor of protein synthesis. FEBS Lett, Vol. 20, pp. 327-329, ISSN 0014-5793

Olsnes, S., Saltvedt, E. \& Pihl, A. (1974). Isolation and comparison of galactose-binding lectins from Abrus precatorius and Ricinus communis. J Biol Chem, Vol. 249, pp. 803810, ISSN 0021-9258; Online ISSN 1083-351X.

Olsnes, S., Refsnes, K., Christensen, T.B. \& Pihl, A. (1975). Studies on the structure and properties of the lectins from Abrus precatorius and Ricinus communis. Biochim Biophys Acta, Vol. 405, pp. 1-10, ISSN 0006-3002

Olsnes, S. \& Pihl, A. (1982). Toxic lectins and related proteins. In. Molecular Actions of Toxins and Viruses. P. Cohen \& S. van Heyningen, (Eds.), Elsevier Press, ISBN-10 0444804005, New York, NY.

Olsnes, S. \& Kozlov, J.V. (2001). Ricin. Toxicon Vol. 39, pp. 1723-1728 ISSN 0041-0101

Olsnes, S. (2004). The history of ricin, abrin and related toxins. Toxicon, Vol. 44, pp. 361-370, ISSN 0041-0101

Olson, M.A., Carra, J.H., Roxas-Duncan, V., et al. (2004). Finding a new vaccine in the ricin protein fold. Protein Eng Des Sel, Vol. 17, pp. 391-397, ISSN 1741 -0126

Pang, Y.P, Park, J.G, Wang, S., et al. (2011). Small-Molecule Inhibitor Leads of RibosomeInactivating Proteins Developed Using the Doorstop Approach. PLoS ONE 6(3): e17883. doi:10.1371/journal.pone.0017883.

Passeron, T., Mantoux, F., Lacour, J.P, et al. (2004). Infectious and toxic cellulitis due to suicide attempt by subcutaneous injection of ricin. Brit J Dermatol, pp. 150-154, ISSN 0007-0963

Pearce, J. (2011). Solzhenitsyn: A Soul in Exile, Ignatius Press, ISBN 9781586174965, Available from http:/ / books.google.com/books?id=lgPwzq0M9lkC

Poli, M.A., Rivera, V.R., Pitt, M.L., et. al. (1996). Aerosolized specific antibody protects mice from lung injury associated with aerosolized ricin exposure. Toxicon, Vol. 34:10371044, ISSN 0041-0101

Poli, M.A., Roy, C., Huebner, K.D., et al. (2007). Ricin. In. Medical Aspects of Biological Warfare, rev ed., Z.F. Dembek (Ed.), pp. 323-335, Borden Institute, Walter Reed Medical Center, ISBN 978-0160797316, Washington, DC

Porter, A., Phillips, G., Smith, L., et al. (2011). Evaluation of a ricin vaccine candidate (RVEC) for human toxicity using an in vitro vascular leak assay. Toxicon, Vol. 58(1), pp. 6875 ISSN 0041-0101

Powers, A. (18 November 2008). Man with ricin is sentenced, In: Los Angeles Times. 07.08.2011. Available from http://articles.latimes.com/2008/nov/18/nation/naricin18

Phillips, R. \& Rix, M. (1999). Annuals and Biennials, Macmillan, ISBN 0333748891. London.

Pinkerton, S.D, Rolfe, R., Auld, D.L., et al. (1999). Selection of Castor for Divergent Concentrations of Ricin and Ricinus communis agglutinin. Crop Science, Vol. 39, pp. 353-357, Online ISSN 1435-0653; Print ISSN 0011-183X

Prigent, J., Panigai, L., Lamourette, P., et al. (2011). Neutralising Antibodies against Ricin Toxin. PLoS ONE 6(5): e20166. doi:10.1371/journal.pone.0020166, ISSN 1932-6203 
Ramsden, C.S, Drayson, M.T., Bell, E.B. (1989). The toxicity, distribution, and excretion of ricin holotoxin in rats. Toxicology, Vol. 55, pp. 161-171, ISSN 0300-483X

Rauber, A. \& Heard, J. (1985). Castor bean toxicity re-examined: a new perspective. Vet Hum Toxicol 27: 490-502, ISSN 0145-6296

Remnick, D. (21 April 1992). KGB plot to assassinate Solzhenitzen reported; Russian Tabloid Says 1971 Attempt Left Dissident Burned, In: The Washington Post, p. D2, 22072011, Available from http:/ / www.highbeam.com/doc/1P2-1001929.html

Research International, Inc. (RII). (2011). A Ricin Primer. 07.08.2011. Available from http://www.resrchintl.com/Ricin_Primer.html

Roberts, L.M., Lamb, F.I., Pappin, D., et al. (1985). The primary sequence of Ricinus communis agglutinin. J Biol Chem, Vol. 260, pp. 15682-15686, ISSN 0021-9258; Online ISSN 1083-351X

Robertus J. (1988). Toxin Structure, In: Immunotoxins, A. Frankel (Ed.), 11-24, Kluwer Academic Publishers, ISBN 0-89838-984-4, Boston, Massachusetts

Robertus, J.D. (1991). The structure and action of ricin, a cytotoxic N-glycosidase. Semin Cell Biol, Vol. 2, pp. 23-30, ISSN 1043-4682

Rotz, L.D., Khan, A.S., Scott, R. et al. (2002). Public Health Assessment of Potential Biological Terrorism Agents. Emerging Infectious Disease, Vol. 8, pp. 225-230.

Sausville, E.A., Headlee, D., Stetler- Stevenson, M., et al. (1995). Continuous infusion of the anti-CD22 immunotoxin IgG-RFB4-SMPT-dgA in patients with B-cell lymphoma: A phase I study. Blood, Vol. 85, pp. 3457-3465, ISSN 0006-497

Scarpa, A. \& Guerci, A. (1982). Various Uses of the Castor Oil Plant (Ricinus communis): A review. J. Ethnopharm, Vol.5, pp. 117-137, ISSN 0378-8741

Schep, L.J., Temple, W.A., Butt, G.A., Beasley, M.D. (2009). Ricin as a Weapon of Mass Terror - Separating Fact from Fiction. Environ Int, Vol. 35 (8), pp. 1267-1271. doi:10.1016/j.envint.2009.08.004. PMID 19767104

Schnell, R., Borchmann, P., Staak, J.O.et al., (2003). Clinical Evaluation of Ricin A-chain Immunotoxins in Patients with Hodgkin's Lymphoma. Ann Oncol, Vol. 14, pp. 729736, ISSN Online1569-8041; ISSN Print 0923-7534

Sharma, P. (29 January 2011). Man Arrested after Ricin Found in House, In: TOPNEWS, 07.08.2011. Available from http://topnews.us/content/233593-man-arrested-afterricin-found-house.

Sims, J., and R.J. Frey. (2005). Castor Oil, In: The Gale Encyclopedia of Alternative Medicine, J. Longe (Ed.), Thomson/Gale, ISBN 0787693960, Farmington Hills, Michigan

Smallshaw, J.E., Firan, A., Fulmer, J.R., Ruback, S.L., Ghetie, V., Vitetta, E.S. (2002). A Novel Recombinant Vaccine Which Protects Mice against Ricin Intoxication. Vaccine, Vol. 20, pp. 3422-3427, ISSN 0264-410X

Smallshaw, J.E., Richardson, J.A., Pincus, S., et al. (2005). Preclinical Toxicity and Efficacy Testing of RiVax, a Recombinant Protein Vaccine against Ricin. Vaccine, Vol. 23, pp. 4775-4784

Smart, J.K. (1997). History of Chemical and Biological Warfare: an American Perspective. In: Medical Aspects of Chemical and Biological Warfare, Part I: Warfare, Weaponry, and the Casualty, R. Zajtchuk (Ed), pp. 9-86, Borden Institute, Washington, DC, Department of the Army, Office of the Surgeon General

Stechmann B, Bai SK, Gobbo E, Lopez R, Merer M, et al. (2010). Inhibition of Retrograde Transport Protects Mice from Lethal Ricin Challenge. Cell, Vol. 141, pp. 231-242, ISSN: 0092-8674 
Stirpe,F. \& Batelli, M.G. (2006). Ribosome-inactivating Proteins: Progress and Problems. Cell Mol Life Sci, Vol. 63(16), pp. 1850-1866

Targosz, D., Winnik, L., Szkolnicka, B. (2002). Suicidal Poisoning with Castor Bean (Ricinus communis) Extract Injected Subcutaneously - Case Report. J Toxicol Clin Toxicol, Vol. 40, p. 398, ISSN 0731-3810

The New York Times. (08 November 1999). National News Briefs; Material for Poison Gas Found in Suspect's Home. 22072011. Available at http:/ / www.nytimes.com/1999/11/08/us/national-news-briefs-material-forpoison-gas-found-in-suspect-s-home.html

TIME Magazine. (16 August 1982). Law: Poison Plot, 07.08.2011. Available from http://www.time.com/time/magazine/article/0,9171,950736-1,00.html

Tizon, T.A. (2004). Post-9/11 Hysteria Blamed in Poison Case. Man Accused of Plotting against Wife Convicted under Anti-terrorist Law, In: The Baltimore Sun, April 20, 2004. 07.08.2011. Available from

http:/ /articles.baltimoresun.com/2004-04-20/news/0404200117_1_olsenpossession-hysteria

Thompson, W. L., Scovill, J. P. \& Pace, J. G. (1995). Drugs that Show Protective Effects from Ricin Toxicity in In Vitro Protein Synthesis Assays. Natural Toxins, 3:369-377. doi: $10.1002 / \mathrm{nt} .2620030508$

USAMRIID. (13 April 2011). USAMRIID Begins Clinical Trial of New Vaccine to Protect Against Ricin Toxin. 07072011. Available from

http:/ / www.usamriid.army.mil/press\%20releases/Ricin\%20News\%20Release\%20 13\%20Apr\%202011.pdf

Vitetta, E.S., Stone, M., Amlot, P., et al. (1991). Phase I Immunotoxin Trial in Patients with Bcell lymphoma. Cancer Res, Vol. 51, pp. 4052-4058, ISSN Online 1538-7445; ISSN Print 0008-5472

Vitetta, E.S., Smallshaw, J.E., Coleman, E., et al. (2005). A Pilot Clinical Trial of a Recombinant Ricin Vaccine in Normal Humans. PNAS, Vol. 103, pp. 2268-2273, ISSN (printed): 0027-8424. ISSN (electronic)

Vitetta, E. (2006). Biomedical and Biodefense Uses for Ricin. An ActionBioscience.org original interview. 08.08.2011. Available from

http://www.actionbioscience. org/newfrontiers/vitetta.html\#primer

Wahome, P., Bai, Y., Neal, L., et al. (2010). Identification of Small-molecule Inhibitors of Ricin and Shiga Toxin using a Cell-based High Throughput Screen. Toxicon, Vol. 56, pp. 313-323, ISSN 0041-0101

Wainwright, M. (2010). Neo-Nazi Ian Davison Jailed for 10 years for Making Chemical Weapon. The Guardian, 14 May 2010, amended 17 May 2010. 07.08.2011. Available from http://www.guardian.co.uk/uk/2010/may/14/neo-nazi-ian-davison-jailedchemical-weapon.

Wannemacher, R. \& Anderson, J. (2005). Inhalation Ricin: Aerosol Procedures, Animal Toxicology, and Therapy, In: Inhalation Toxicology, 2nd ed., H. Salem (Ed.), CRC Press, 973-979, ISBN 0849340497, Boca Raton, Florida

Watson, W.A., Litovitz, T.L., Rodgers, G.C., et al. (2003). 2002 Annual Report of the American Association of Poison Control Centers Toxic Exposure Surveillance System. Am J Emerg Med, Vol. 21, pp. 353-421. 
Wortmann, G. (2004). Ricin Toxin, In: Physician's Guide to Terrorist Attack, M.J. Roy (Ed.), 175179, Human Press Inc., ISBN 1592596630, Totowa, New Jersey

Youn Y.S., Na, D.H., Yoo, S.D., et al. (2005). Carbohydrate-specifically Polyethylene Glycolmodified Ricin A-chain with Improved Therapeutic Potential. Int J Biochem Cell Biol, Vol. 37, pp. 1525-1533, ISSN: 1357-2725

Zilinskas, RA 1997. Iraq's Biological Weapons: The Past or Future. JAMA, Vol. 278, pp. 418424, ISSN 0098-7484 


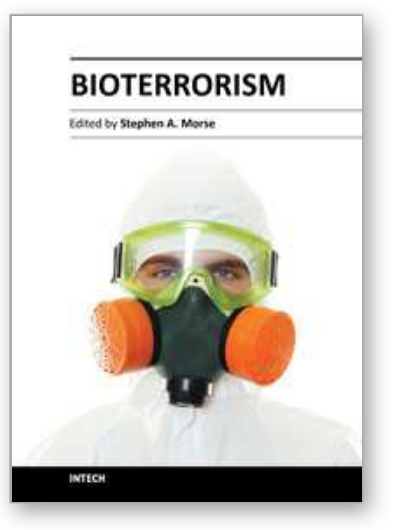

\author{
Bioterrorism \\ Edited by Dr. Stephen Morse
}

ISBN 978-953-51-0205-2

Hard cover, 192 pages

Publisher InTech

Published online 28, March, 2012

Published in print edition March, 2012

This book consists of nine chapters, written by international authorities, discussing various aspects of bioterrorism preparedness and response. Five of the chapters are agent-specific and highlight the pathogenesis, prevention and treatment, and the potential of specific organisms (Rickettsia and Yersinia pestis) or toxins (ricin, botulinum neurotoxins, and staphylococcal enterotoxins) to be used for nefarious purposes. Four chapters discuss different aspects of detecting and responding to a bioterrorism attack. These include methods for spatio-temporal disease surveillance, international laboratory response strategies, detection of botulinum neurotoxins in food and other matrices, and the use of physical methods (ie Raman spectroscopy) to detect spores.

\title{
How to reference
}

In order to correctly reference this scholarly work, feel free to copy and paste the following:

Virginia I. Roxas-Duncan and Leonard A. Smith (2012). Ricin Perspective in Bioterrorism, Bioterrorism, Dr. Stephen Morse (Ed.), ISBN: 978-953-51-0205-2, InTech, Available from:

http://www.intechopen.com/books/bioterrorism/ricin-perspective-in-bioterrorism

\section{INTECH}

open science | open minds

\section{InTech Europe}

University Campus STeP Ri Slavka Krautzeka 83/A 51000 Rijeka, Croatia Phone: +385 (51) 770447

Fax: +385 (51) 686166 www.intechopen.com

\section{InTech China}

Unit 405, Office Block, Hotel Equatorial Shanghai No.65, Yan An Road (West), Shanghai, 200040, China 中国上海市延安西路65号上海国际贵都大饭店办公楼405单元 Phone: +86-21-62489820

Fax: $+86-21-62489821$ 
(C) 2012 The Author(s). Licensee IntechOpen. This is an open access article distributed under the terms of the Creative Commons Attribution 3.0 License, which permits unrestricted use, distribution, and reproduction in any medium, provided the original work is properly cited. 